Biochimica et Biophysica Acta, 422 (1976) 73-86

(C) Elsevier Scientific Publishing Company, Amsterdam - Printed in The Netherlands

BBA 67683

\title{
PARTIAL PURIFICATION AND PROPERTIES OF A CHROMATIN- ASSOCIATED PHOSPHOPROTEIN KINASE FROM RAT LIVER NUCLEI
}

LORA E. RIKANS and RAYMOND W. RUDDON

Department of Pharmacology, The University of Michigan Medical School, Ann Arbor, Mich. 48104 (U.S.A.)

(Received July 11th, 1975)

\section{Summary}

A phosphoprotein kinase (EC 2.7.1.37) $\mathrm{KIVb}$, from rat liver nuclei, was purified 75-fold by phosphocellulose chromatography and gel filtration on Sephadex G-200. The enzyme, which has an apparent molecular weight of 55000 , phosphorylates casein and chromatin-bound nonhistone proteins more readily than histones or ribosomal proteins. It exhibits an absolute requirement for divalent cation with optimum activity at $15-20 \mathrm{mM} \mathrm{Mg}^{2+}$. Maximal kinase activity is achieved at $100 \mathrm{mM} \mathrm{NaCl}$. The $\mathrm{pH}$ vs. activity curve is biphasic with optima at $\mathrm{pH} 6.5$ and $\mathrm{pH} 8.0$. The $K_{\mathrm{m}}$ value for casein is $280 \mu \mathrm{g} / \mathrm{ml}$ and the $K_{\mathrm{m}}$ for ATP is $6 \cdot 10^{-6} \mathrm{M}$.

Kinase KIVb phosphorylates numerous nonhistone nuclear proteins as shown by electrophoretic analysis. The addition of kinase $\mathrm{KIVb}$ to reaction mixtures containing nonhistone proteins results in the phosphorylation of a spectrum of polypeptides similar to those that are phosphorylated by endogenous nuclear kinases. Nonhistone proteins bound to chromatin appear to be better substrates for $\mathrm{KIVb}$ than nonhistones dissociated from chromatin. A comparison of nuclear phosphoproteins phosphorylated either in the intact animal or in vitro (by the addition of kinase $\mathrm{KIVb}$ ) indicates some differences and some similarities in the patterns of phosphorylation.

\section{Introduction}

Phosphorylation of nuclear nonhistone proteins has been correlated with gene activation in eukaryotes $[1-6]$. Knowledge of the phosphorylation reaction should lead to a better understanding of the specific regulation of gene transcription. For this reason attention has been focused on the enzymes presumably responsible for nonhistone protein phosphorylation, and recent reports describe phosphoprotein kinase (EC 2.7.1.37) activities in the nuclei of 
several different mammalian tissues [7-14]. The present report describes the partial purification and characterization of a major nonhistone phosphoprotein kinase from rat liver nuclei.

\section{Experimental Procedures}

\section{Materials}

Casein (Hammersten) was purchased from Schwarz/Mann. Histone I (calf thymus), cyclic AMP and cyclic GMP were obtained from Sigma. Mixed histones (calf thymus, unfractionated) and phospholipase $\mathrm{C}$ were from Worthington Biochemical Corp. Cellulose phosphate (Whatman No. P-11) was purchased from H. Reeve Angel and Co., and Sephadex G-75 and G-200 (Fine) were purchased from Pharmacia Fine Chemicals Inc. $\left[{ }^{3} \mathrm{P}_{\mathrm{i}}\right]$ (carrier-free) and $\left[\gamma^{-{ }^{3}} \mathrm{P}\right] \mathrm{ATP}$ ( 7 to $12 \mathrm{Ci} / \mathrm{mmol}$ ) were obtained from New England Nuclear Corp.

\section{Methods}

Isolation of nuclear nonhistone proteins. A modification [9] of the method of Chauveau et al. [15] was used for the preparation of purified rat liver nuclei. The nonhistone proteins were extracted by homogenizing the nuclear pellets in $0.4 \mathrm{M} \mathrm{NaCl}, 0.05 \mathrm{M}$ Tris $\cdot \mathrm{HCl}(\mathrm{pH} 7.5)$ followed by stirring at $0^{\circ} \mathrm{C}$. Centrifugation of the homogenate at $27000 \times \mathrm{g}$ for $30 \mathrm{~min}$ yielded a supernatant solution containing $50 \%$ or more of the nuclear protein and $95 \%$ of the nuclear kinase activity. Polyacrylamide gel electrophoresis in the presence of sodium dodecyl sulfate indicated that histones were almost entirely absent from this fraction. Furthermore, the preparations did not contain significant protease activity, as assayed by the method of Weisenthal and Ruddon [16]. Therefore, the $0.4 \mathrm{M} \mathrm{NaCl-buffer}$ extract was chosen as a suitable starting material for further purification of the nuclear phosphoprotein kinase activities and for the isolation of nonhistone protein to be used as substrate. All subsequent procedures involving nonhistone protein preparation and purification of the nonhistone kinase were carried out at $4^{\circ} \mathrm{C}$.

In order to prepare nonhistone protein which was relatively free of endogenous kinase activity and thus more suitable to be employed as substrate for the enzyme, the $0.4 \mathrm{M} \mathrm{NaCl}$-buffer extract was first dialyzed against a buffer containing $0.05 \mathrm{M}$ Tris $\cdot \mathrm{HCl}(\mathrm{pH} 7.5)$ and $0.05 \mathrm{M} \mathrm{NaCl}$. The $0.05 \mathrm{M} \mathrm{NaCl}$ soluble proteins were recovered by centrifugation, and 8-20 $\mathrm{mg}$ was applied to a $1.5 \mathrm{~cm} \times 26 \mathrm{~cm}$ column of phosphocellulose previously equilibrated with $0.05 \mathrm{M}$ Tris $\cdot \mathrm{HCl}(\mathrm{pH} 7.5), 0.05 \mathrm{M} \mathrm{NaCl}$. The protein peak eluted with $0.05 \mathrm{M}$ NaCl-buffer contained most of the protein but only a small fraction (2-3\%) of the total kinase activity applied to the column. This was the fraction employed as nonhistone substrate in the kinase reactions.

Preparation of nuclear phosphoproteins. Calcium phosphate gel was added to nonhistone protein in a ratio of $2 \mathrm{mg}$ of gel per $\mathrm{mg}$ protein for the purification of nuclear phosphoproteins using the method described by Kish and Kleinsmith [11].

Separation of nuclear kinase activities by phosphocellulose chromatography. Phosphocellulose column chromatography was used to separate several 
phosphoprotein kinase activities present in the $0.4 \mathrm{M} \mathrm{NaCl}$-buffer extract of rat liver nuclei. The nuclear extract containing up to $80 \mathrm{mg}$ of protein was applied to a $1.5 \mathrm{~cm} \times 26 \mathrm{~cm}$ phosphocellulose column which had been previously equilibrated with $0.4 \mathrm{M} \mathrm{NaCl}, 0.05 \mathrm{M}$ Tris $\cdot \mathrm{HCl}(\mathrm{pH} \mathrm{7.5)}$. Fractionation was accomplished by applying buffers with increasing $\mathrm{NaCl}$ concentration in stepwise fashion. The buffers were (1) $0.4 \mathrm{M} \mathrm{NaCl}$ in $0.05 \mathrm{M}$ Tris $\cdot \mathrm{HCl}(\mathrm{pH} 7.5$ ), 0-125 ml, (2) $0.6 \mathrm{M} \mathrm{NaCl}$ in $0.05 \mathrm{M}$ Tris $\cdot \mathrm{HCl}(\mathrm{pH} \mathrm{8.1)}, 126-240 \mathrm{ml}$, and (3) $1.2 \mathrm{M} \mathrm{NaCl}$ in $0.05 \mathrm{M}$ Tris $\cdot \mathrm{HCl}(\mathrm{pH} 8.1), 241-310 \mathrm{ml}$. Columns were eluted at a flow rate of approximately $15 \mathrm{ml} / \mathrm{h}$ and $5-\mathrm{ml}$ fractions were collected.

Sephadex gel filtration. Sephadex G-200 columns $(1.5 \mathrm{~cm} \times 86 \mathrm{~cm})$ were prepared with the pre-swollen gel and equilibrated with $0.5 \mathrm{M} \mathrm{NaCl}, 0.05 \mathrm{M}$ Tris $\cdot \mathrm{HCl}\left(\mathrm{pH} \mathrm{7.5)}\right.$ at an operating pressure of $20 \mathrm{~cm} \mathrm{H}_{2} \mathrm{O}$. This operating pressure produced a flow rate of $6 \mathrm{ml} / \mathrm{h}$. Fractions from the phosphocellulose column containing the major kinase activity were pooled (usually $8-15 \mathrm{ml}$ containing 2-5 mg of protein) and carefully layered over the column of Sephadex G-200. Elution was with $0.5 \mathrm{M} \mathrm{NaCl}, 0.05 \mathrm{M}$ Tris $\cdot \mathrm{HCl}(\mathrm{pH} \mathrm{7.5)}$ buffer for $200 \mathrm{ml}$, and $5-\mathrm{ml}$ fractions were collected.

For estimation of molecular weight by gel filtration, the elution volume of the enzyme activity was compared to the elution volumes, determined under identical conditions, of several standard proteins.

Isolation of chromatin, ribosomes, and nucleoli. Chromatin was prepared from purified rat liver nuclei using a modification of the method of Huang and Huang [17]. All procedures were carried out at $4^{\circ} \mathrm{C}$. Nuclei were homogenized twice in $75 \mathrm{mM} \mathrm{NaCl}, 24 \mathrm{mM}$ EDTA, $5 \mathrm{mM} \mathrm{NaHSO}{ }_{3}(\mathrm{pH} 8.0)$ and centrifuged at $1000 \times g$. The resulting crude chromatin fraction was washed 3 times with $50 \mathrm{mM}$ Tris $\cdot \mathrm{HCl}(\mathrm{pH} \mathrm{8.0)}, 5 \mathrm{mM} \mathrm{NaHSO}$ and then washed 3 times with 10 $\mathrm{mM}$ Tris $\cdot \mathrm{HCl}(\mathrm{pH} 8.0), 5 \mathrm{mM} \mathrm{NaHSO}{ }_{3}$. The final chromatin pellet was resuspended in Buffer A $\left(100 \mathrm{mM} \mathrm{NaCl}, 20 \mathrm{mM} \mathrm{Mg}\left(\mathrm{CH}_{3} \mathrm{CO}_{2}\right)_{2}\right.$ and $50 \mathrm{mM}$ Tris $\mathrm{HCl}, \mathrm{pH} 8.0$ ), and homogenized with a tissuemizer using three 15-s bursts. Chromatin isolated by this procedure had a protein/DNA mass ratio of 1.5 and RNA/DNA mass ratio of 0.075 . Ribosomes were prepared from fresh rat livers by deoxycholate treatment of microsomes as described by Cohen and Ruddon [18]. Nucleoli were prepared from fresh rat livers by the method of Muramatsu and Busch [19].

Phosphoprotein kinase assay. The original protein kinase assay described earlier [9] was used to estimate the phosphoprotein kinase activity in column fractions. Optimal conditions for the major nuclear kinase activity were determined and were used in the kinase assays involving the purified enzyme fraction. Kinase activity was determined under optimal conditions in a reaction mixture $(0.5 \mathrm{ml})$ which contained $(\mathrm{mM})$ : Tris $\cdot \mathrm{HCl}(\mathrm{pH} 8.0), 50 ; \mathrm{NaCl}, 100$; $\mathrm{Mg}\left(\mathrm{CH}_{3} \mathrm{CO}_{2}\right)_{2}, 20$; ATP, 0.01-0.04 (containing 1.0-5.0 $\mu \mathrm{Ci}$ of $\left[\gamma^{3}{ }^{2} \mathrm{P}\right] \mathrm{ATP}$ ) and purified enzyme $(2 \mu \mathrm{g}$ protein). Unless otherwise noted, the substrate was casein and was present at a concentration of $300 \mu \mathrm{g} / \mathrm{ml}$. The reaction was started with the addition of $\left[\gamma^{3}{ }^{2} \mathrm{P}\right] \mathrm{ATP}$ and, after $5 \mathrm{~min}$ of incubation at $37^{\circ} \mathrm{C}$, was stopped by the addition of $1.0 \mathrm{ml}$ of cold $10 \%$ trichloroacetic acid containing $40 \mathrm{mM}$ sodium pyrophosphate and $1 \mathrm{mM}$ unlabeled ATP. The acidprecipitable material was collected on cellulose acetate filters and counted as previously described [9] . 
Acrylamide gel electrophoresis. Samples were prepared for sodium dodecyl sulfate gel electrophoresis by overnight dialysis at $23^{\circ} \mathrm{C}$ against a buffer containing $0.01 \mathrm{M}$ sodium phosphate $(\mathrm{pH} 7.0), 0.1 \%$ sodium dodecyl sulfate, $0.1 \% \beta$-mercaptoethanol. Samples were heated at $100^{\circ} \mathrm{C}$ for $3 \mathrm{~min}$ immediately prior to electrophoresis on $10 \%$ polyacrylamide gels. Electrophoresis was performed according to the procedure of Weber and Osborn [20]. Two sizes of gels were used, $6 \mathrm{~mm} \times 60 \mathrm{~mm}$ for samples of 20-150 $\mu \mathrm{g}$ protein and $8 \mathrm{~mm} \times$ $90 \mathrm{~mm}$ for samples of 150-300 $\mu \mathrm{g}$ protein. Following electrophoresis, gels were stained with Coomassie brilliant blue [20] and either photographed or scanned at a wavelength of $550 \mathrm{~nm}$ using a Gilford linear gel transport. Gels which contained $\left[{ }^{32} \mathrm{P}\right]-$ or $\left[{ }^{3} \mathrm{P}\right]$ phosphoproteins were sliced with a Mickle gel slicer. The gel slices $(0.5$ or $1.0 \mathrm{~mm})$ were incubated at $65^{\circ} \mathrm{C}$ for $24 \mathrm{~h}$ in tightly-capped counting vials with $15 \mathrm{ml}$ of toluene solution containing $3 \%$ Protosol and 0.8\% 2,5-diphenyloxazole (PPO) prior to counting.

Polyacrylamide gel electrophoresis under non-denaturing conditions was performed on crude and purified enzyme fractions after dialysis against a suitable buffer. The gel systems employed were the $\mathrm{pH} 9.5$ system of Davis [21] with no stacking gel, the $\mathrm{pH} 8.1$ system described by Kish and Kleinsmith [11], and the $\mathrm{pH} 4.3$ system (minus stacking gels) of Reisfeld et al. [22].

Animals and isotope administration. Male albino rats, weighing $200 \mathrm{~g}$, were given an intraperitoneal injection of $2.5 \mathrm{mCi}{ }^{33} \mathrm{P}_{\mathrm{i}}$. Animals were killed $1 \mathrm{~h}$ after injection and their livers removed and used for the isolation of nonhistone protein.

Other analytical methods. Protein concentration in column fractions was estimated by measuring absorbancy at a wavelength of $280 \mathrm{~nm}$. Otherwise, protein concentration was measured by the method of Lowry et al. [23] using crystalline bovine serum albumin as standard. DNA was determined with diphenylamine following the procedure of Burton [24] with calf thymus DNA as standard.

\section{Results}

Separation of nuclear phosphoprotein kinase activities by phosphocellulose chromatography

Phosphocellulose chromatography of the $0.4 \mathrm{M} \mathrm{NaCl}$-buffer extract of rat liver nuclei yielded 6 kinase activity peaks (Fig. 1) when assayed with casein as the substrate. No additional peaks were seen if column fractions were assayed with nonhistone protein $(67 \mu \mathrm{g})$ as substrate or assayed with endogenous substrate only. Nuclear kinase KI, KII, KIII and KIV represent 4 separate enzyme activities based on differences in $\mathrm{pH}$ optimum, enzyme stability, and substrate specificity [9]. Nuclear kinase KV and KVI have not been studied.

The major phosphoprotein kinase activity peak, KIV, was chosen for further purification. Fig. 1 illustrates that phosphocellulose chromatography effectively separates kinase KIV from the bulk of the nuclear proteins present in the $0.4 \mathrm{M} \mathrm{NaCl}$-buffer extract. However, purification data (Table I) indicated that the phosphocellulose chromatography step provided only a 3-fold purification of the enzyme. This number underestimates the degree of purification since the 

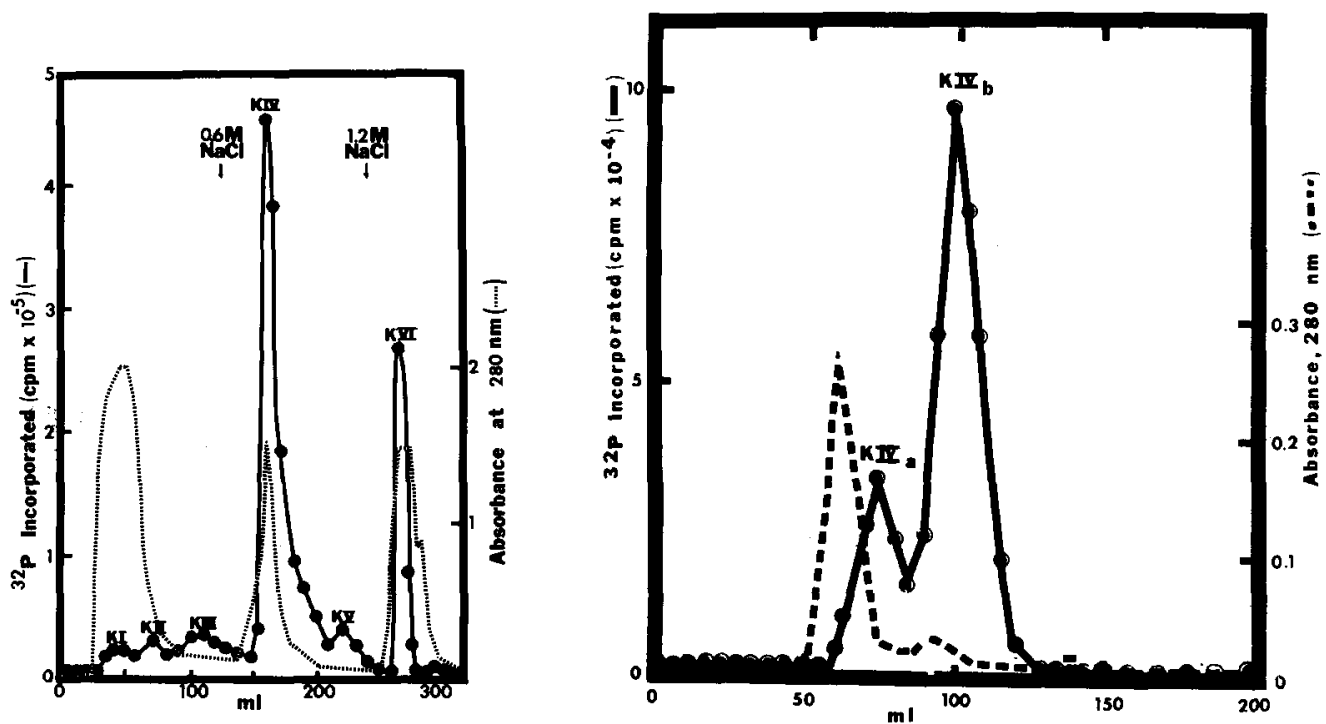

Fig. 1. Phosphocellulose chromatography of the $0.4 \mathrm{M} \mathrm{NaCl-buffer}$ extract of rat liver nuclei. The column was developed as described under Methods.

Fig. 2. Gel filtration of nuclear kinase KIV on Sephadex G-200. The column was developed as described under Methods; $0.2 \mathrm{ml}$ aliquots of each column fraction were used in the kinase assay.

kinase activity assayed in the $0.4 \mathrm{M} \mathrm{NaCl}$-buffer extract is the sum of 6 activities, and kinase KIV is only one of them.

\section{Gel filtration of nuclear kinase KIV on Sephadex G-200}

Nuclear kinase KIV could be resolved into 2 peaks of activity by gel filtration on a column of Sephadex G-200 (Fig. 2). The major kinase activity, $\mathrm{KIVb}$, eluted at a volume consistent with a molecular weight of 55000 (Fig. 3). At least a 75-fold purification of the major nuclear phosphoprotein kinase was obtained using these procedures (Table I). Purification and recovery

\section{TABLE I}

PURIFICATION OF NUCLEAR PHOSPHOPROTEIN KINASE KIVb

The purification procedures and phosphoprotein kinase assay were carried out as described under Methods.

\begin{tabular}{|c|c|c|c|c|}
\hline Fraction & $\begin{array}{l}\text { Total protein } \\
(\mathrm{mg})\end{array}$ & $\begin{array}{l}\text { Specific } \\
\text { activity } \\
(\mathrm{pmol} / \mathrm{min} / \mathrm{mg})\end{array}$ & $\begin{array}{l}\text { Purification } \\
\text { of activity } \\
\text { (-fold) }\end{array}$ & $\begin{array}{l}\text { Recovery } \\
\text { of activity } \\
(\%)\end{array}$ \\
\hline Whole cell homogenate & 5040 & 270 & & \\
\hline $1000 \times g$ supernatant & 2480 & 280 & & \\
\hline $1000 \times g$ pellet & 2200 & 220 & 1 & 100 \\
\hline Purified nuclei & 80 & 1400 & 6.4 & $\mathbf{2 3}$ \\
\hline $0.4 \mathrm{M} \mathrm{NaCl}$-buffer extract & 52 & 2110 & 9.6 & 23 \\
\hline KIV & 5.25 & 6030 & 27.4 & 7 \\
\hline KIVb & 0.75 & 16500 & 75.0 & 2.5 \\
\hline
\end{tabular}



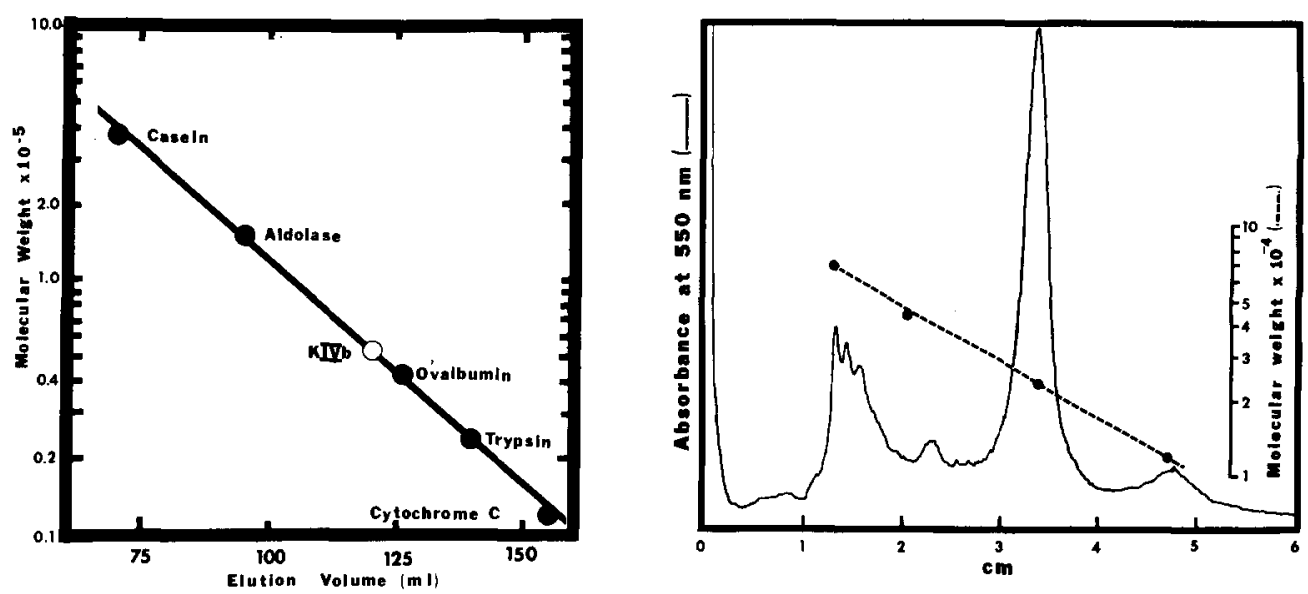

Fig. 3. Estimation of molecular weight for nuclear kinase KIVb by gel filtration on Sephadex G-200. Gel filtration of kinase $\mathrm{KIVb}$ was performed as described under Methods.

Fig. 4. Electrophoretic analysis of kinase KIVb on sodium dodecyl sulfate gels. Kinase KIVb (45 $\mu \mathrm{g})$ was layered on a $10 \%$ acrylamide gel and subjected to sodium dodecyl sulfate electrophoresis as described under Methods. The reference proteins and their molecular weights were bovine serum albumin, 68000 ; ovalbumin, 43 000; trypsin, 23 000: and cytochrome c, 12400 . Direction of migration was from left to right.

values were based on the activity in the $1000 \times g$ pellet (crude nuclear fraction) because approximately one half of the total cellular casein kinase activity was extra-nuclear (Table I). A similar distribution of casein kinase activities was reported by Matsumura and Takeda [25].

\section{Polyacrylamide gel electrophoresis}

Further purification of the KIVb fraction was attempted utilizing gel electrophoresis under nondenaturing conditions. However, KIVb proteins remained as a single band after electrophoresis in 3 different buffer systems ( $\mathrm{pH}$ 9.5, $\mathrm{pH} 8.1$, and $\mathrm{pH} 4.3$ ). Sodium dodecyl sulfate gel electrophoresis in $10 \%$ polyacrylamide gels was performed on each fraction obtained in the purification procedure. The $0.4 \mathrm{M} \mathrm{NaCl}$ buffer extract of rat liver nuclei contained at least 30 polypeptides, most of them having molecular weights in the range of $30000-100000$, which is typical for nonhistone nuclear protein preparations. The KIV fraction contained about 20 of these polypeptide bands, but the purified KIVb fraction was resolved into 6 polypeptide bands (Fig. 4). The 25 000-dalton polypeptide proved to be a contaminant and not a component of the enzyme. This was indicated in an experiment in which urea treatment of the KIVb fraction allowed the separation of the 25000 - from the 50000 to 70 000-dalton polypeptides on a column of Sephadex G-75. Fractions were dialyzed to remove urea, assayed for kinase activity, and then subjected to sodium dodecyl sulfate electrophoresis. The kinase activity peak obtained from the Sephadex G-75 column contained 50 000- to 70000 -dalton polypeptides but not a 25 000-dalton component. Thus, the 25 000-molecular weight component was a polypeptide which co-purified with kinase KIVb but was not necessary for kinase activity. 


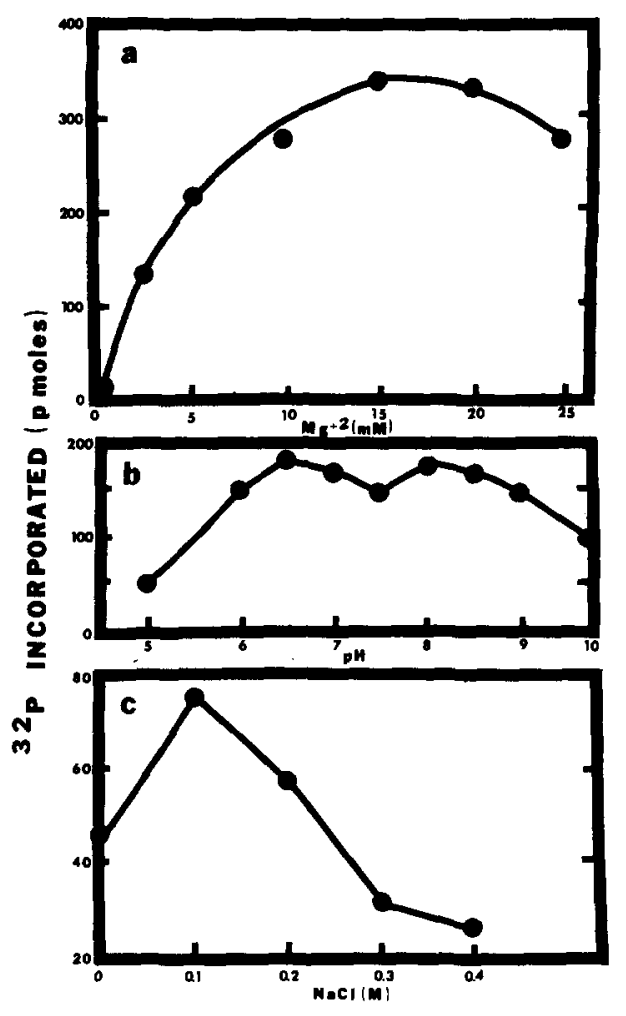

Fig. 5. Properties of kinase KIVb activity. (a) Magnesium saturation curve; (b) Effect of pH. Buffer in the standard reaction mixture was replaced by (1) $100 \mathrm{mM}$ sodium acetate, pH 5.0. (2) $100 \mathrm{mM}$ Pipes buffer, pH 6.0, 6.5, or 7.0, or (3) $100 \mathrm{mM}$ Tris - HCl, pH 7.0, 7.5, 8.0, 8.5, 9.0, or 10.0; (c) Effect of NaCl. Phosphoprotein kinase activity was assayed using the procedure described under Methods.

\section{Kinetic properties of kinase KIVb}

The phosphorylation of casein catalyzed by kinase KIVb was linear for $5 \mathrm{~min}$ at $37^{\circ} \mathrm{C}$ and $0-4 \mu \mathrm{g}$ of KIVb protein in the standard reaction volume. Lineweaver-Burk double-reciprocal plots of initial velocity versus casein or ATP concentration were used to calculate $K_{\mathrm{m}}$ values for the substrates. The $K_{\mathrm{m}}$ value for casein was $280 \mu \mathrm{g} / \mathrm{ml}$ and the $K_{\mathrm{m}}$ for ATP was $6 \cdot 10^{-6} \mathrm{M}$.

\section{Effect of magnesium, $\mathrm{pH}$, and $\mathrm{NaCl}$}

Nuclear kinase $\mathrm{KIVb}$ exhibited an absolute requirement for divalent cation as demonstrated in Fig. 5a. The concentration of magnesium that gave optimum phosphorylation was $15-20 \mathrm{mM}$; higher concentrations inhibited the reaction. Other investigators have demonstrated that maximal activity of partially purified protein kinases from rat liver nuclei is achieved in the presence of $\mathrm{Mg}^{2+}$. Other divalent cations, including $\mathrm{Ba}^{2+}, \mathrm{Be}^{2+}, \mathrm{Ca}^{2+}, \mathrm{Co}^{2+}, \mathrm{Mn}^{2+}, \mathrm{Sr}^{2+}$ and $\mathrm{Zn}^{2+}$, could not fully substitute for $\mathrm{Mg}^{2+}$ in this reaction $[10,13]$. The maximal activity of kinase $\mathrm{KIVb}$ was in the $\mathrm{pH}$ range of 6.5 to 8.0 . A biphasic $\mathrm{pH}$ optimum curve was demonstrated repeatedly (Fig. 5b). Increasing the concentration of $\mathrm{NaCl}$ from 0 to $0.4 \mathrm{M}$ resulted in stimulation followed by inhibition 
TABLE II

SUBSTRATE SPECIFICITY OF KINASE KIVb

The phosphorylation reactions were carried out as described under Methods except that the indicated substrates were present in a concentration of $200 \mu \mathrm{g}$ protein per ml. Intact ribosomes rather than extracted ribosomal proteins were used. Incorporation of ${ }^{32} \mathrm{P}$ due to endogenous kinase activity was subtracted from the results. The percentage of total activity that was due to endogenous kinase activity was $35 \%$ for nonhistone protein, $60 \%$ for chromatin, and $98 \%$ for ribosomes. In Expt. 2, samples were heated for 20 $\min$ at $90^{\circ}$ after the addition of $10 \%$ trichloroacetic acid and prior to filtering.

\begin{tabular}{lcc} 
& 32 P Incorporated by kinase KIVb (pmol) \\
Protein substrate & Expt. 1 & Expt. 2 \\
\hline Casein & 33.2 & 38.0 \\
Nonhistone protein & 3.3 & 3.0 \\
Chromatin & 8.0 & 7.2 \\
Ribosomes & 0.5 & \\
Mixed Histones & 1.2 & 0.4 \\
Histone I & & \\
\hline
\end{tabular}

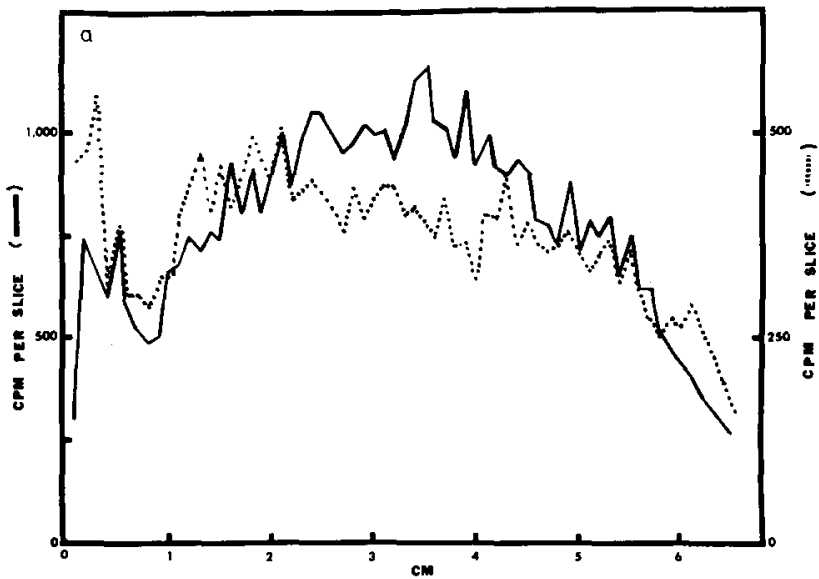

b

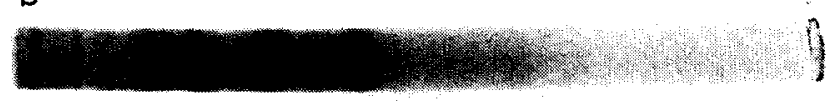

Fig. 6. Sodium dodecyl sulfate gel electrophoresis of $\left[{ }^{32} \mathrm{P}\right]$ nonhistone proteins. (a), Nonhistone protein was incubated with $\left[\gamma_{-32}{ }^{2}\right.$ P] A TP in the presence (- - or absence $(\ldots \ldots)$ of added kinase KIVb. The incubation reaction, in a total volume of $6.0 \mathrm{ml}$, contained $(\mathrm{mM}): \mathrm{NaCl}, 100 ; \mathrm{Mg}\left(\mathrm{C}_{2} \mathrm{H}_{3} \mathrm{O}_{2}\right)_{2}, 20 ;$ Tris $\mathrm{HCl}(\mathrm{pH} 8.0), 50 ;\left[\gamma^{32} \mathrm{P}\right] \mathrm{ATP}, 0.005(6 \mu \mathrm{Ci})$; and nonhistone protein $(200 \mu \mathrm{g} / \mathrm{ml})$. When included, kinase $\mathrm{KIVb}$ was twice the usual amount, or $8 \mu \mathrm{g} / \mathrm{ml}$. Maximum ${ }^{32} \mathrm{P}$ incorporation was reached after $1 \mathrm{~h}$ of incubation at $37^{\circ} \mathrm{C}$. Incubations were terminated by the addition of cold $10 \%$ trichloroacetic acid containing $40 \mathrm{mM}$ sodium pyrophosphate and $1 \mathrm{mM}$ unlabeled ATP. Samples were heated at $90^{\circ} \mathrm{C}$ for 20 min to hydrolyze nucleic acids. The protein precipitate was pelleted, washed with cold $5 \%$ trichloroacetic acid, and then with cold acetone. The final pellets were dissolved with $1 \%$ sodium dodecyl sulfate, $4 \mathrm{M}$ urea, $0.1 \% \beta$-mercaptoethanol and boiled $3 \mathrm{~min}$ just prior to electrophoresis on $8 \mathrm{~mm} \times 90 \mathrm{~mm}$ gels. Gels were layered with $275 \mu \mathrm{g}$ protein containing $58650 \mathrm{cpm}^{32} \mathrm{P}(-\longrightarrow$ ) or $25300 \mathrm{cpm} 32 \mathrm{P}(\cdots \cdots)$. The gels were sliced into $1 \mathrm{~mm}$ slices and the first 65 slices of each gel were assayed for radioactivity as described under Methods. Ordinates are represented by different scales in order to illustrate the similarities in migration of the 32 P-labeled peaks. (b) Migration of nonhistone proteins in sodium dodecyl sulfate polyacrylamide gels. The nonhistone proteins in the $0.4 \mathrm{M} \mathrm{NaCl-buffer}$ extract of rat liver nuclei were subjected to sodium dodecyl sulfate electrophoresis as described in the text. Following electrophoresis the gels were stained with Coomassie brilliant blue. Migration was from left to right. 
of kinase activity (Fig. 5c). The optimum concentration of $\mathrm{NaCl}$ was $0.10 \mathrm{M}$. Identical results were produced by $\mathrm{KCl}$ and $\mathrm{NaCl}$ with kinase $\mathrm{KIV}$ activity.

\section{Substrate specificity}

Results presented in Table II indicate that kinase KIVb exhibited a high degree of preference for casein as a substrate. Various rat liver cellular fractions including nonhistone protein, chromatin, and ribosomes were examined for their ability to act as substrate for the enzyme. Ribosomes were examined because ribosomal proteins are found in the nucleus [26] and nucleolar proteins are phosphorylated [27-29] by a protein kinase reported to be associated with nucleoli $[28,29]$. In our studies ribosomes and histones were poor substrates for kinase KIVb, while chromatin and nonhistone protein were intermediate substrates (Table II). Since whole ribosomes were used in these studies their ability to act as substrate might have been limited by a lack of exposed phosphorylation sites. It should be noted that ribosomes and chromatin contained high endogenous kinase activities. When nonhistone protein or chromatin fractions were heated $\left(5 \mathrm{~min}\right.$ at $\left.60^{\circ} \mathrm{C}\right)$ to inactivate endogenous kinase activity, there was a concomitant loss of phosphoryl acceptor ability. The apparent preference of kinase KIVb for casein must be interpreted cautiously. One would have to quantitate serine and threonine residues of the various substrates on a molar basis before one could determine the true specificity of the enzyme.

Sodium dodecyl sulfate gel electrophoresis was performed on nonhistone protein or chromatin protein after incubating with $\left[\gamma^{3}{ }^{2} \mathrm{P}\right] \mathrm{ATP}$, with or without added kinase KIVb (Fig. 6). There was a 2.3-fold stimulation (above endogenous activity) of ${ }^{32} \mathrm{P}$ incorporation into nonhistone protein after the addition of $\mathrm{KIVb}$ (note the different ordinates in Fig. 6). The distribution of radioactivity in the gel slices indicated that numerous polypeptides were phosphorylated in the reaction and that many of the same nonhistone polypeptide species which were phosphorylated by kinase $\mathrm{KIVb}$ were also phosphorylated by endogenous kinase contained in the nonhistone protein fraction.

\section{Effect of cyclic nucleotides}

Various concentrations of the cyclic nucleotides, adenosine $3^{\prime}, 5^{\prime}$-monophosphate (cyclic AMP) and guanosine $3^{\prime}, 5^{\prime}$-monophosphate (cyclic GMP), were tested for their ability to stimulate or inhibit the activity of kinase KIVb. Neither cyclic AMP $\left(10^{-8}\right.$ to $\left.10^{-5} \mathrm{M}\right)$ nor cyclic GMP $\left(10^{-8}\right.$ to $\left.10^{-5} \mathrm{M}\right)$ significantly affected the phosphorylation of casein by kinase KIVb.

\section{Location of kinase KIVb}

Since rat liver cytosol also contains casein kinases [30-32], a comparison was made of the major casein kinase activities from cytosol and nucleus in an attempt to discover a property that might be unique to the nuclear enzyme. The casein kinase activity in both fractions appeared to be identical with respect to affinity for phosphocellulose, $\mathrm{pH}$ optimum, $\mathrm{Mg}^{2+}$ requirement and optimum concentration, and stimulation by $\mathrm{NaCl}$. Although casein kinase activity was found in cytosol as well as nuclei, its specific activity was several times higher in nuclei (Table I). When kinase activity was measured in chromatin, 
TABLE III

ENDOGENOUS PHOSPHOPROTEIN KINASE ACTIVITY IN SOME PARTICULATE CELL FRACTIONS

The phosphorylation reactions were carried out with chromatin, whole nucleoli, or intact ribosomes $(38-40 \mu \mathrm{g}$ protein) as described under Methods except that kinase KIVb was not added. Where indicated, casein was present in a concentration of $300 \mu \mathrm{g} / \mathrm{ml}$.

\begin{tabular}{lll}
\hline Enzyme source & Casein & $\begin{array}{l}\text { Specific activity } \\
\text { (pmol/min/mg protein) }\end{array}$ \\
\hline Chromatin & - & 212 \\
Chromatin & + & 608 \\
Nucleoli & - & 22 \\
Nucleoli & + & 94 \\
Ribosomes & - & 80 \\
Ribosomes & + & 80 \\
\hline
\end{tabular}

nucleoli, or ribosomes under conditions optimal for KIVb, the highest specific activity for casein phosphorylation was found in the chromatin fraction (Table III). Moreover, $75 \%$ of the endogenous kinase activity in chromatin is kinase KIV, based on purification by phosphocellulose chromatography. These data suggest that kinase KIVb exists in a chromatin-associated form and that chromatin proteins are substrates for it.

\section{Other properties of nuclear kinase KIVb}

The addition of $25 \mu \mathrm{g}$ of phospholipase $\mathrm{C}$ (phosphatidyl-choline phosphohydrolase) to a standard reaction mixture resulted in no loss of kinase KIV activity. Kinase activity was also unaffected by $10^{-4} \mathrm{M} N$-ethylmaleimide. Beta-mercaptoethanol did not prevent the slow, steady loss of activity that occurred in kinase KIVb upon storage. Although fraction KIV could be stored at $4^{\circ} \mathrm{C}$ for 4 days or at $-20^{\circ} \mathrm{C}$ for more than 1 year with no loss of activity, kinase KIVb was much less stable. A significant reduction in kinase KIVb activity was observed when the enzyme was left at $0^{\circ} \mathrm{C}$ for $8 \mathrm{~h}$ (up to $50 \%$ ) or when kinase $\mathrm{KIVb}$ was stored at $-80^{\circ} \mathrm{C}(10-20 \%$ in a week). Kinase $\mathrm{KIVb}$ was completely inactivated by incubation at $60^{\circ} \mathrm{C}$ for $5 \mathrm{~min}$.

\section{In vivo labelling of nuclear phosphoproteins}

Sodium dodecyl sulfate gel electrophoresis was used to compare in vivo phosphorylation of nuclear phosphoproteins with in vitro phosphorylation in the presence of kinase KIVb. Rats were injected with ${ }^{33} \mathrm{P}_{\mathrm{i}} 1 \mathrm{~h}$ prior to sacrifice. The ${ }^{33} \mathrm{P}$-labeled nonhistone protein fraction extracted from the livers of these animals was then utilized as the substrate for kinase $\mathrm{KIVb}$ and $\left[\gamma^{-3}{ }^{2} \mathrm{P}\right]$ ATP. Thus, the same preparation of nonhistone protein was labeled both in vivo and in vitro. In these experiments the nuclear phosphoproteins were further purified [11] from the total nonhistone protein fraction prior to electrophoretic analysis. The gels were stained, scanned, sliced, and counted as described under Methods, and the results are illustrated in Fig. 7. The nuclear phosphoproteins were not uniformly labeled; that is, some proteins contained 

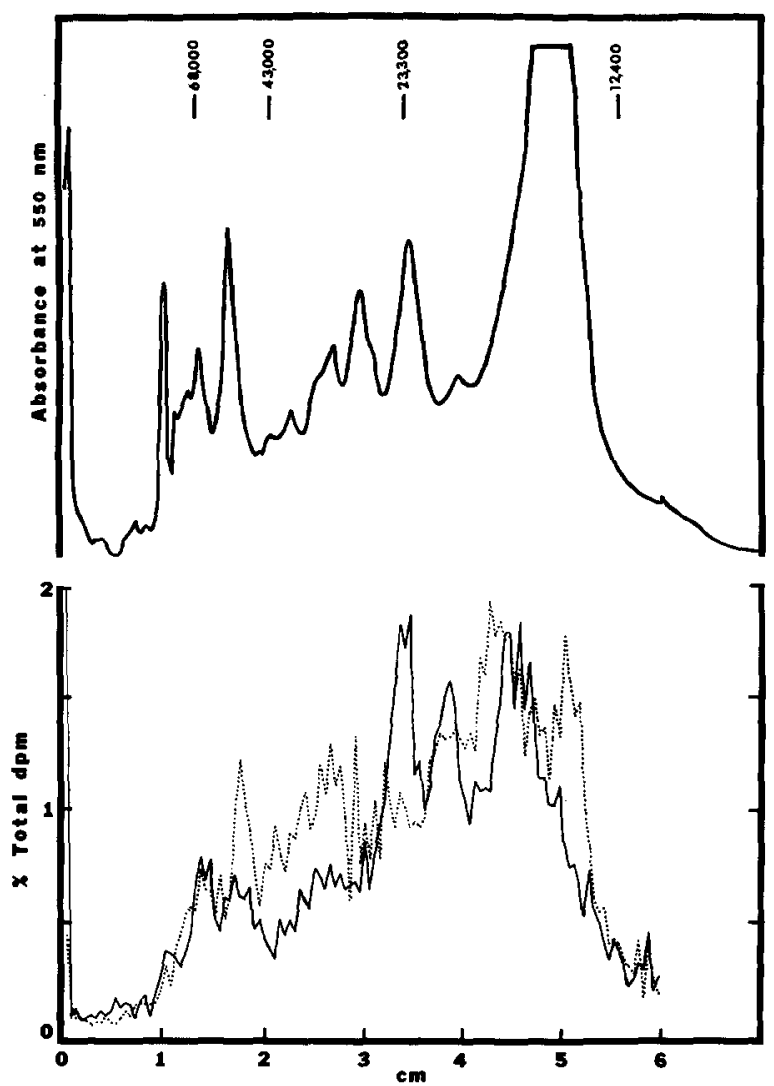

Fig. 7. Sodium dodecyl sulfate polyacrylamide gel electrophoresis of nuclear phosphoproteins phosphorylated in vivo with ${ }^{33} \mathrm{P}_{\mathrm{i}}$ and in vitro with $\left[\gamma-{ }^{32} \mathrm{P}\right] \mathrm{ATP}$ and kinase $\mathrm{KIVb}$. The incubation was carried out as described for Fig. 6 , but the substrate $w$ as $\left[{ }^{33} \mathrm{P}\right]$ nonhistone protein labeled in vivo. The $\left[{ }^{33} \mathrm{P}\right]$ nonhistone protein was obtained from purified nuclei by extraction with $0.4 \mathrm{M} \mathrm{NaCl}$, dialysis to $0.05 \mathrm{M} \mathrm{NaCl}$, and separation on phosphocellulose chromatography. After $60 \mathrm{~min}$ the incubation was stopped and calcium phosphate was added to the labeled nonhistone protein for the purification of phosphoproteins. The purified phosphoproteins $(143 \mu \mathrm{g})$ were subjected to sodium dodecyl sulfate gel electrophoresis on $6 \mathrm{~mm} \times 70 \mathrm{~mm}$ gels. The details of these procedures are described under Methods. The direction of migration was from left to right. Top, Coomassie blue stained phosphoproteins scanned at $550 \mathrm{~nm}$. The marker proteins were bovine serum albumin, ovalbumin, trypsin, and cytochrome $c$. Bottom, radioactivity profile of nuclear phosphoproteins labeled with ${ }^{33} \mathrm{P}$ in vivo $\left(\longrightarrow\right.$ ) and ${ }^{32} \mathrm{P}$ in vitro $(\cdots \cdots)$. The gel, which contained $8500 \mathrm{dpm}$ of $33 \mathrm{P}$ and $14000 \mathrm{dpm}$ of $32 \mathrm{P}$, was sliced into $0.5 \mathrm{~mm}$ slices, and each slice was assayed for radioactivity.

more radioactivity than others. The pattern of phosphorylation in vitro was similar to the pattern obtained in vivo in that a heterogenous group of nonhistone protein was phosphorylated in both cases. In order to rule out the possibility that ${ }^{33} \mathrm{P}$ was reutilized as a substrate for the in vitro reaction, the turnover of ${ }^{33} \mathrm{P}$-labeled nonhistone protein was determined in vitro in the presence of excess unlabeled ATP. No loss of ${ }^{3}{ }^{3} \mathrm{P}$ from the nonhistone protein fraction was observed during a 60-min incubation under the same conditions employed in the phosphorylation reactions. 


\section{Discussion}

This study describes the partial purification and characterization of a major nonhistone phosphoprotein kinase activity in rat liver nuclei. The estimation of a 75-fold purification achieved by our procedures is most likely an underestimation for two reasons. First, the original activity measurement in crude nuclei is erroneously large because it includes the activities of all the nuclear kinases. Secondly, the purified KIVb kinase is somewhat unstable, and all of its activity is not recovered from the Sephadex column (Table I). Based on the elution profiles obtained from column chromatography and on the banding patterns from gel electrophoresis, kinase KIVb would appear to be more highly purified than the relative purification based on specific activities would suggest.

Several reports characterizing purified nuclear protein kinases from rat liver $[10,13,14]$ have recently appeared. Unlike our purification procedure, these purifications began with an ammonium sulfate precipitation of a nuclear extract. Desjardins et al. [10] and Takeda et al. [13] found only two kinase activities in rat liver nuclei, whereas Dastugue et al. [32] found two kinase activities which could both be further fractionated into two or three other activities. In contrast, Kish and Kleinsmith [11] found 12 distinct nuclear kinases in beef liver and stated that this may be an underestimation of the actual number of kinases present. In our study 6 nuclear kinase activities were separated by phosphocellulose chromatography. The major kinase, KIV, was further resolved into two activities by gel filtration with Sephadex G-200. More evidence is needed to ascertain whether KIVa and KIVb (Fig. 2) are distinct enzymes or whether KIVa is simply an aggregate of KIVb. That kinases can exist in multiple forms which may be different aggregates of a single protein kinase has been shown for the phosvitin kinase from rat liver cytosol [33] and for the cyclic AMP-dependent protein kinase from heart muscle [34]. It would be interesting to determine what role, if any, aggregation plays in the regulation of kinase activity.

It appears that our kinase KIVb may correspond to kinase NI of Desjardins et al. [10] and kinase $A_{2}$ of Takeda et al. [13] since a number of properties of the three enzyme preparations are similar. Purification data, including specific activities, for the purified kinase $\mathrm{NI}$ and $\mathrm{A}_{2}$ indicate that these kinases were less pure than kinase KIVb. This may be an important factor in explaining differences between our data and theirs. Dastugue et al. [32] have also described two nuclear kinases obtained from rat liver, but neither of these appears to have properties similar to kinase KIVb.

A knowledge of the substrate specificity of kinase KIVb could provide a clue as to the role of that enzyme in the control of cellular processes. Therefore, we tested the ability of several components of the liver cell to act as phosphoryl acceptors for kinase KIVb. This study demonstrates that chromatin-bound nonhistone proteins are substrates for a purified nuclear kinase. Furthermore, data in Table II suggest that chromatin-bound nonhistone proteins may be better substrates for kinase $\mathrm{KIVb}$ than nonhistone proteins which are not associated with chromatin. This raises the possibility that the conformation of NHP most favorable for phosphoryl acceptor activity may depend on an 
appropriate interaction between nonhistone proteins, histones, and DNA. A strict conformational requirement for phosphoryl acceptor activity is also suggested by the fact that heating of either chromatin or nonhistone protein results in a loss of substrate activity along with the loss of kinase activity.

The heterogeneity of the nuclear phosphoprotein population which can be phosphorylated by kinase KIVb is of interest. One might expect more specificity from an enzyme involved in the regulation of gene activity. Perhaps modulators of phosphoprotein kinase provide the required specificity. For example, modulators which alter the substrate specificity for cyclic AMP-dependent histone kinases have been found in rat mammary gland [35]. Moreover, histones may act as regulators of nonhistone protein phosphorylation in that the addition of individual histones to in vitro kinase reactions has been reported to stimulate [36,37] or inhibit [37] phosphorylation of nonhistone protein. Another possibility is that specificity is provided by the balance between phosphorylation and dephosphorylation of nonhistone protein. The pattern of phosphorylation of nonhistone protein in the intact cell must reflect the sum of the activities of phosphoprotein kinases and phosphatases in the presence of modulators of their activity.

\section{Acknowledgement}

This work was supported by National Institutes of Health Grant GM-19863.

\section{References}

1 Kleinsmith, L.F., Allfrey, V.J. and Mirsky, A.E. (1966) Science 154, 780-781

2 Gershey, E.L. and Kleinsmith, L.J. (1969) Biochim. Biophys. Acta 194, 519-525

3 Turkington, R.W, and Riddle, M. (1969) J. Biol. Chem. 244, 60406046

4 Teng, C.S., Teng, C.T. and Allfrey, V.G. (1971) J. Biol. Chem. 246, 3567-3609

5 Ahmed, K, and Ishida, H. (1971) Mol. Pharmacol. 7, 323-327

6 Jungmann, R.A. and Schweppe, J.S. (1972) J. Biol. Chem, 247, 5535-5542

7 Takeda, M., Yamamura, H. and Ohga, Y. (1971) Biochem. Biophys. Res. Commun. 42, 103-110

8 Kamiyama, M. and Dastugue, B. (1971) Biochem. Biophys. Res. Commun. 44, 29-36

9 Ruddon, R.W. and Anderson, S.L. (1972) Biochem. Biophys. Res. Commun. 46, 1499-1507

10 Desjardins, P.R., Lue, P.F., Liew, C.C. and Gornall, A.G. (1972) Can. J. Biochem. 50, 1249-1259

11 Kish, V.M. and Kleinsmith, L.J. (1974) J. Biol. Chem. 249, 750-760

12 Brade, W.P., Thomson, J.A., Chiu, J.-F., Hnilica, L.S. (1974) Exp. Cell Res. 84, 183-190

13 Takeda, M., Matsumura, S. and Nakaya, Y. (1974) J. Biochem. 75, 743-751

14 Kruh, J., Dastugue, B., Defer, N., Kamiyama, M. and Tichonicky, L. (1974) Biochimie 56, 995-1001

15 Chauveau, J., Moule, Y. and Rouiller, C. (1956) Exp. Cell Res. 11, 317-321

16 Weisenthal, L.M. and Ruddon, R.W. (1973) Cancer Res. 33, 2923-2935

17 Huang, R.C.C. and Huang, P.C. (1969) J. Mol. Biol. 39, 365-378

18 Cohen, A.M. and Ruddon, R.W. (1971) Mol. Pharmacol. 7, 484-489

19 Muramatsu, M. and Busch, H. (1967) in Methods in Cancer Research (Busch, H., ed.) Vol. 2, pp. 303-319, Academic Press, New York

20 Weber, K. and Osborn, M. (1969) J. Biol. Chem. 244, 4406-4412

21 Davis, B.J. (1964) Annals N.Y. Acad. Sci. 121, 404-427

22 Reisfeld, R.A., Lewis, U.J. and Williams, D.E. (1962) Nature 195, 281-283

23 Lowry, O.H., Rosebrough, N.J., Farr, A.L. and Randall, R.J. (1951) J. Biol. Chem. 193, 265-275

24 Burton, K. (1968) Methods Enzymol. 12, 163-166

25 Matsumura, S. and Takeda, M. (1972) Biochim. Biophys. Acta 289, 237-241

26 Prestayko, A.W., Klomp, G.R., Schmoll, D.J. and Busch, H. (1974) Biochem istry 13, 1945-1951

27 Olson, M.O., Orrick, L.R., Jones, C. and Busch, H. (1974) J. Biol. Chem. 249, 2823--2827

28 Grummt, I. (1974) FEBS Lett. 39, 125-128 
29 Grummt, I. and Grummt, F. (1974) FEBS Lett. 39, 129-132

30 Baggio, B., Pinna, L.A., Moret, V. and Siliprandi, N. (1970) Biochem. Biophys. Acta 212, 515-517

31 Kumon, A., Nishiyama, K., Yamamura, H. and Nishizuka, Y. (1972) J. Biol. Chem. 247, $3726-3735$

32 Dastugue, B., Tichonicky, L. and Kruh, J. (1974) Biochemie 56, 491-500

33 Baggio, B. and Moret, V. (1971) Biochim. Biophys. Acta 250, 346-350

34 Rubin, C.S., Erlichman, J, and Rosen, O.M. (1972) J. Biol. Chem. 247, 36-44

35 Majumder, G.C. (1974) Biochem. Biophys. Res. Commun. 58, 756-761

36 Kaplowitz, P.B., Platz, R.D. and Kleinsmith, L.J. (1971) Biochim. Biophys. Acta 229, $739-748$

37 Johnson, E.M., Vidali, G., Littau, V.C. and Allfrey, V. (1973) J. Biol. Chem. 248, 7595-7600 